AKRUAL 5 (2) (2014): 168-182 $e$-ISSN: 2502-6380

\title{
AKRUAL
}

Jurnal Akuntansi

http://fe.unesa.ac.id/ojs/index.php/akrl

\section{PEMANFAATAN WEBSITE DIREKTORAT JENDERAL PAJAK OLEH AKUNTAN PEMERINTAH DI KALIMANTAN TIMUR}

\author{
Muhammad Subhan \\ Abd. Gafur \\ Email: mhmmd_subhan@yahoo.com \\ abd.gafur@gmail.com \\ Artikel diterima: .20 November 2013 \\ Terakhir direvisi: 3 Januari 2014
}

\begin{abstract}
This research aimed to examine the effect ofperceived usefulness variable, perceived ease of use variable and psychological attachment variable to attitude inusing information technology. Attitude will influence the behavior specifically inutilizing information technology concern shown bythe behavior. Data was obtained through the questionnaire survey with a purposely sampling technique with the criteria, accountants who utilize tax website that www.pajak.go.id in performing their work. Accountants who are being sample do f this study is accountant who are in government organizations. Analysis of the data in this research uses Structural Equation Modeling (SEM) with an alternative method of PLS (Partial Least Square) which is assisted with the application program Smart PLS.

Based onthe results of the research be concluded that 1) there is no significant relationship between perceived usefulness and attitude variables in the utilizationof taxwebsite (www.pajak.go.id.); 2) there is asignificant relationship between the variables of perceived ease of use and attitude in the use of website taxation (www.pajak.go.id); 3) there is no significant relationship between the variables of psychological attachment and attitude in the utilization of tax website(www.pajak.go.id); 4) there is asignificant relationship between attitude and behavior variables intention to use the website taxation (www.pajak.go.id).
\end{abstract}

Key Words: perceived usefulness, perceived ease of use, psychologicalattachment, attitude, behavior intention.

\section{PENDAHULUAN}

Dengan semakin cepatnya perkembangan teknologi informasi, pergerakan ekonomi dan ketidakpastian merupakan beberapa faktor yang mendasari pentingnya investasi teknologi informasi. Teknologi informasi telah menjadi bagian penting dalam proses bisnis organisasi. Hartono (2003) yang dikutip Darsono (2005) 
mengatakan bahwa teknologi informasi memungkinkan perusahaan memiliki kemampuan untuk beradaptasi.

Direktorat Jenderal Pajak (DJP) sebagai lembaga pemerintah yang bertanggung jawab terhadap penerimaan negara dari pajak dituntut untuk mendukung pembangunan dengan target pendapatan pajak yang cukup besar. Dari tahun 2002 hingga tahun 2012, target penerimaan pajak telah melonjak hingga 473,33\%. Hal tersebut menandakan dinamisasi kehidupan bangsa kian menuntut kemandirian fiskal yang harus dipenuhi demi kesuksesan pembangunan.Sistem pemungutan pajak di Indonesia menganut Self Assesment System dimana wajib pajak diberikan kewajiban untuk menghitung, membayar dan melaporkan sendiri pajak yang terutangnya. Sehingga untuk memenuhi tuntutan target penerimaan pajak maka DJP telah memanfaatkan teknologi sebagai sarana utama untuk mendorong kesadaran masyarakat untuk memenuhi kewajibannya. Direktorat Jenderal Pajak telah meningkatkan pelayanan perpajakan kepada masyarakat melalui teknlogi informasi melalui jaringan internet yang beralamat di www.pajak.go.id.

Hartono (2005) menjelaskan informasi yang dapat berguna harus didukung oleh tiga pilar yaitu relevan (relevance) karena informasi tersebut sesuai dengan kebutuhan pemakainya untuk pengambilan keputusan, tepat waktu (timeliness) karena informasi tersebut dapat diperoleh pada saat dibutuhkan dan akurat (accurate) karena nilai yang terdapat dalam informasi tersebut tepat (tidak bias). Lucas dan Spitter (1999) yang dikutip oleh Wijayanto (1999) yang menyatakan bahwa apabila teknologi informasi dapat dimanfaatkan secara efektif maka anggota dalam organisasi harus mampu untuk menggunakan teknologi informasi dengan baik, sehingga memberikan kontribusi terhadap kinerjanya.

Model yang dapat digunakan untuk mengukur penerimaan teknologi informasi oleh pemakainya adalah TAM (Technology Acceptance Model) yang dikembangkan oleh Davis (1989) dengan berlandaskan TRA (Technology Reason Action) yang dikembangkan oleh Fishbein dan Ajzein (1975). Pernyataan Davis, Bargozi dan Warshaw yang dikutip Malhotra dan Galetta (1999) menunjukkan tujuan dari TAM adalah menyediakan penjelasan dari penentuan penerimaan komputer yang secara umum, kemampuan menjelaskan perilaku pemakai untuk semua pemakai akhir (end user) teknologi komputer dan populasi pemakai. Malhotra dan Galetta (1999) menyebutkan TAM dan TRA sebagai dasar teori hubungan sebab akibat dari dua faktor yang membangun sikap (attitude) yaitu penerimaan kegunaan (perceived usefulness) dan penerimaan kemudahan menggunakan (perceived ease of use). Dalam penelitian Malhotra dan Galetta (1999) menambahkan variabel pengaruh psikologis (psychological attachment) dalam pemanfaatan teknologi informasi.

Peneliti dalam hal ini akan melakukan penelitian berdasarkan variabelvariabel perceived usefulness, perceived ease of use dan psychological attachment. Variabel-variabel tersebut akan mempengaruhi penerimaan www.pajak.go.id melalui variabel intervening attitude yang mempengaruhi perilaku yang khusus dalam pemanfaatan www.pajak.go.id tersebut yang ditunjukkan dengan variabel behavior 
intention. Penelitian dilakukan pada masyarakat yang berprofesi sebagai Akuntan pemerintah di wilayah Kalimantan Timur.

Dari pemaparan yang telah disampaikan sebelumnya, penulis merumuskan beberapa masalah sebagai berikut:

1. Apakah variabel perceived usefulness mempengaruhi pemanfaatan www.pajak.go.idpada akuntan di Kalimantan Timur?

2. Apakahvariabel perceived ease of use mempengaruhi www.pajak.go.idpada akuntan di Kalimantan Timur?

3. Apakahvariabel psychological attachment mempengaruhi pemanfaatan www.pajak.go.idpada akuntan di Kalimantan Timur?

\section{KAJIAN PUSTAKA}

\section{TRA (Theory Reason Action)dan TAM (Technology Acceptance Model)}

Menurut Dillon dan Morris dalam Malhotra dan Galletta (1999) definisi TRA (Theory Reason Action) adalah hubungan antara keyakinan (belief), sikap (attitude), norma-norma (norms), perhatian yang khusus (behavior intention) dan perilaku (behavior) seseorang. Menurut teori tersebut, perilaku individu ditentukan oleh satu perhatian untuk menunjukkan perilaku. Malhotra dan Galletta (1999) menyatakan TRA mempelajari model psikologis sosial yang diperhatikan dengan penentuan perilaku yang diharapkan secara sadar. Menurut TRA, kinerja seseorang dari perilaku yang khusus ditentukan oleh perhatian perilaku (behavior intention) untuk menunjukkan perilaku (behavior). Perhatian perilaku (behavior intention) yang ditentukan oleh sikap (attitude) seseorang dan norma subjektif (subjective norm). Sun dan Zhang (2006) mendefinisikan norma subjektif adalah persepsi seseorang bahwa banyak orang yang penting bagi dia berfikir bahwa dia sebaiknya menunjukkan atau tidak menunjukkan perilakunya dalam pertanyaan.

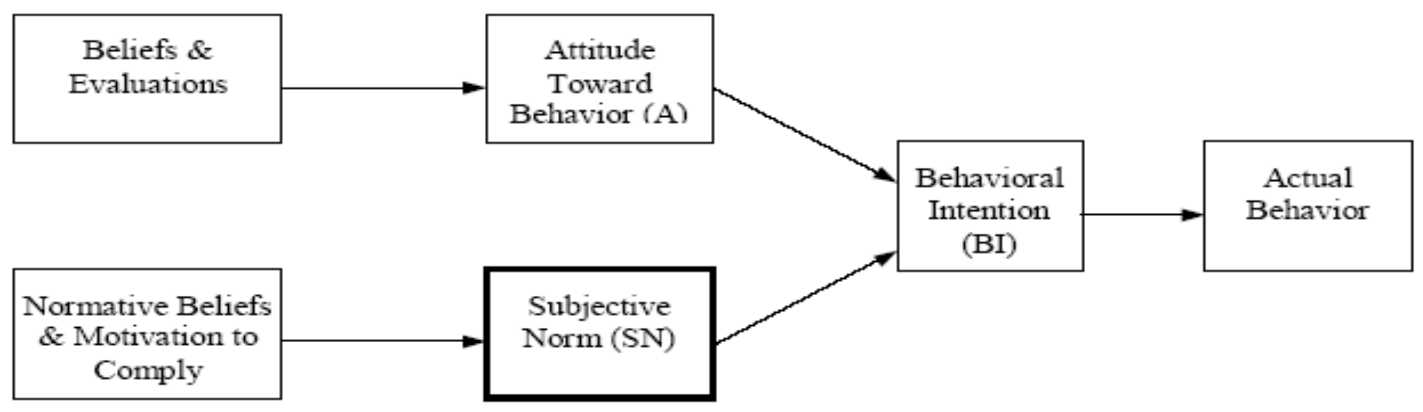

Gambar 1. TRA (Theory Reasoned Action)

Sumber: Succi dan Walter (1999) berdasarkan Fishbein dan Ajzen (1975)

TAM (Technology Acceptance Model) yang dikembangkan oleh Davis (1989) dengan berlandaskan TRA (Theory Reason Action) yang dikembangkan oleh Fishbein dan Ajzein (1975). Menurut Davis (1989) yang dikutip oleh Kim, Chun dan 
Song menyatakan bahwa dalam model TAM terdapat dua faktor penentu dalam pemanfaatan sistem yaitu penerimaan kemudahan menggunakan (perceived ease of use) dan penerimaan kegunaan (perceived usefulness). Perceived ease of use dan perceived usefulness menenentukan sikap (attitude) dalam memanfaatkan teknologi informasi. Sikap (attitude)akan mempengaruhi perilaku khusus yang ditunjukkan melalui perhatian perilaku (behavior intention) dalam memanfaatkan teknologi informasi. Sehingga perhatian perilaku (behavior intention) dalam menggunakan teknologi akan mempengaruhi penerimaan teknologi yang digunakan. Perceived usefulness juga dapat mempengaruhi perilaku yang khusus dalam memanfaatkan teknologi yang ditunjukkan melalui perhatian prilaku (behavior intention) dalam memanfaatkan teknologi secara langsung.

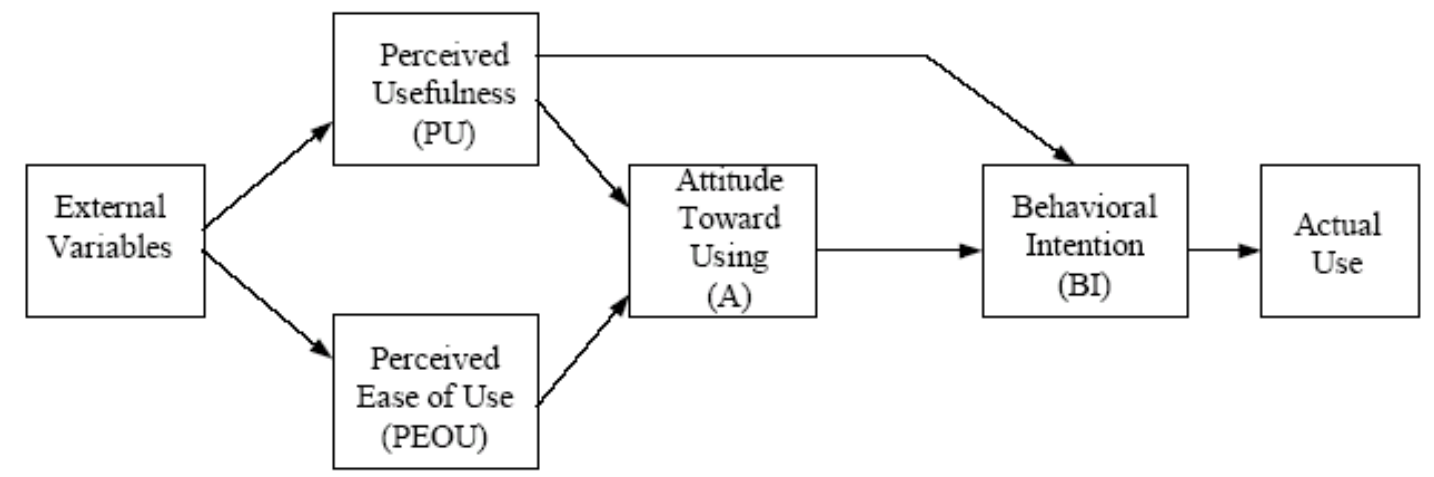

\section{Gambar 2. TAM (Technology Acceptance Model) Sumber: Malhotra dan Galetta (1999) Berdasarkan Model Davis (1989)}

Dalam penelitian ini, peneliti menggunakan variabel perceived usefulness, perceived ease of use dan psychological attachment. Variabel-variabel tersebut dijelaskan sebagai berikut:

1. Weber (1999) menjelaskan bahwa variabel penerimaan kegunaan (perceived usefulness) yaitu keinginan calon pemakai bahwa dengan menggunakan sistem aplikasi yang khusus akan meningkatkan kinerjanya.

2. Weber(1999) menjelaskan bahwa variabel penerimaan kemudahan menggunakan (perceived ease of use) yaitu tingkatan dari harapan pemakai bahwa dalam pemanfaatan sistem tidak memerlukan banyak usaha (free of effort).

3. Malhotra dan Galletta (1999) menjelaskan definisi psychological attachment adalah tingkatan atas komitmen pemakai sistem informasi terhadap sistem informasi yang digunakan berdasarkan pengaruh social influence. Social influence adalah tingkat pengaruh pihak lain terhadap individu mengenai penggunaan teknologi informasi.

4. Malhotra dan Galletta (1999) menambahkan satu faktor penentu dalam pemanfaatan sistem variabel psychological attachment selain perceived usefulness dan perceived ease of usekedalam model TAM yang dikembangkan Davis (1989). 
Variabel perceived usefulness, perceived ease of use dan psychological attachment akan mempengaruhi variabel sikap (attitude) dalam pemanfaatan teknologi informasi. Sikap (attitude) akan mempengaruhi perilaku yang khusus dalam pemanfaatan teknologi melalui perhatian perilaku (behavior intention). Gardner dan Amoroso (2004) mengatakan behavior intention adalah mengukur kekuatan dari sebuah perhatian untuk menunjukkan prilaku yang khusus. Behavior intention adalah penentu yang baik untuk pemakaian yang aktual dari sebuah teknologi.

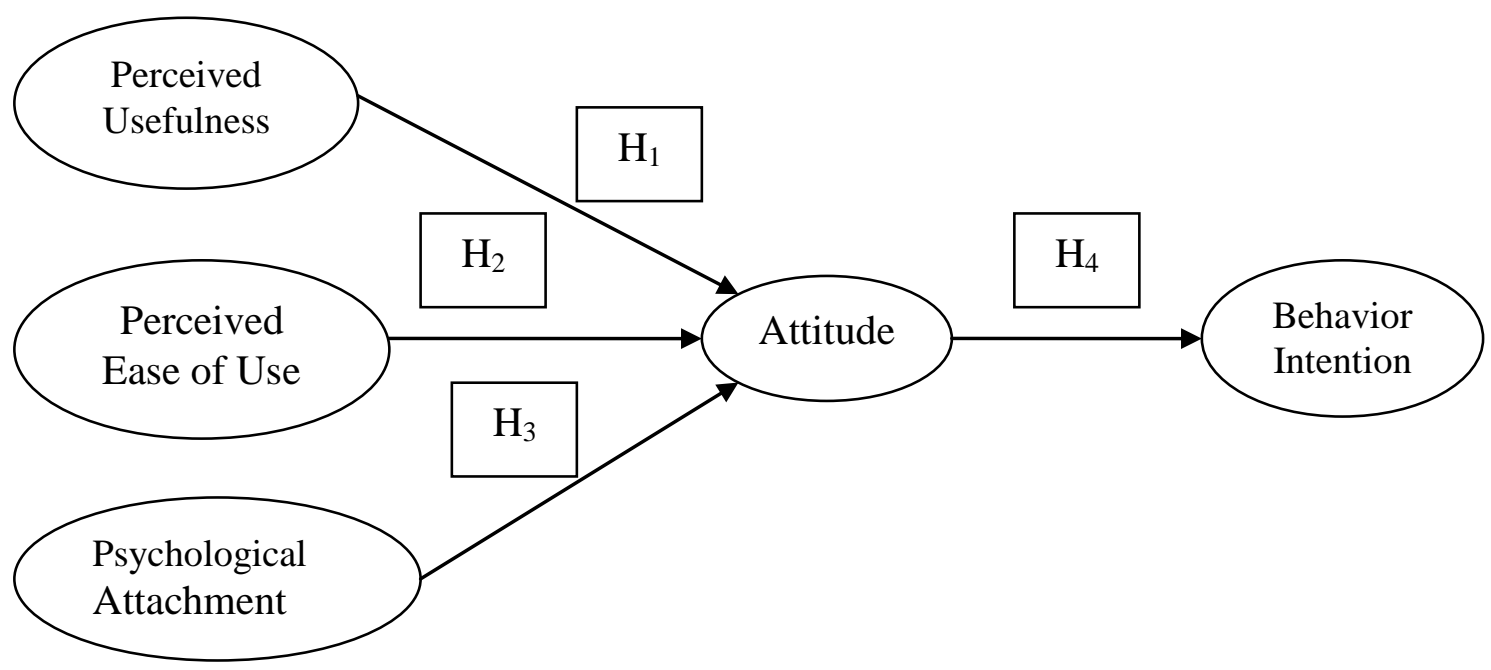

Gambar 3. Model Penelitian

\section{Pengembangan Hipotesis}

$\mathbf{H}_{1}$ :Terdapat pengaruh yang signifikan antara faktor perceived usefulness dan attitude dalam pemanfaatanwww.pajak.go.id.

Berdasarkan definisi dari Davis (1989) yang dikutip Kang (1998) mengatakan bahwa perceived usefulness adalah tingkatan pemikiran individu bahwa dengan menggunakan teknologi akan memperbaiki kinerjanya. Umarji (2005) menyebutkan bahwa perceived usefulness merupakan persepsi praktisi mengenai kinerja aktivitas teknologi informasi dalam mencapai kepuasan kerja (job satisfaction) dan prospek karir mereka.

Berdasarkan penelitian yang dilakukan oleh Hubona dan Geitz (1997) dengan menggunakan TAM (Technology Acceptance Model) yang diajukan Davis (1989) tampak bahwa perkembangan teknologi informasi akan efektif jika terdapat kecocokan antara teknologi yang digunakan dan tugas-tugas yang dikerjakan dan antara karakteristik individu dan teknologi yang digunakan. Sehingga keyakinan (beliefs) dan sikap (attitude) adalah instrumen dalam mendorong penerimaan pemakai atas teknologi informasi yang baru. 
Berdasarkan penjelasan diatas, maka peneliti akan mengajukan hipotesis pengaruh faktor perceived usefulness terhadap attitude dalam pemanfaatanwww.pajak.go.id.

$\mathbf{H}_{2}$ :Terdapat pengaruh yang signifikan antara faktor perceived ease of use dan attitude dalam pemanfaatanwww.pajak.go.id.

Berdasarkan definisi dari Davis (1989) yang dikutip oleh Kang (1998) mengatakan bahwa perceived ease of use adalah tingkat keyakinan seseorang bahwa menggunakan teknologi informasi dapat dilakukan dengan sedikit usaha (free of effort). Hubona dan Geitz (1997) menyatakan bahwa variabel ekternal baik itu individu maupun organisasi juga merupakan faktor penting yang harus dipertimbangkan dengan memperhatikan proses mengadopsi teknologi informasi yang baru. Karena variabel eksternal yaitu kategori pekerjaan, pengalaman yang dimiliki terhadap sistem, dan pengalaman terhadap komputer memiliki pengaruh langsung dan tidak langsung terhadap perilaku (behavior) yang harus dipertimbangkan.

Heslin (1996) menyatakan bahwa orang-orang yang berbeda menunjukkan persepsi yang berbeda-beda terhadap kemudahan dalam menggunakan teknologi informasi terhadap sistem yang sama. Hal tersebut menunjukkan bahwa perbedaan pekerjaan akan mempengaruhi penerimaan terhadap kemudahan dalam menggunakan teknologi informasi dengan sistem yang sama karena setiap orang memiliki pengalaman dan kemampuan yang berbeda dalam menggunakan teknologi informasi. Berdasarkan penjelasan di atas, peneliti mengajukan hipotesis pengaruh faktor perceived ease of use terhadap attitude dalam pemanfaatanwww.pajak.go.id.

$\mathbf{H}_{3}$ :Terdapat pengaruh yang signifikan antara faktor psychological attachment dan attitude dalam pemanfaatan www.pajak.go.id.

Iqbaria (1999) yang dikutip Wijayanto (2003) mendefinisikan social influence adalah tingkat pengaruh pihak lain terhadap individu mengenai penggunaan teknologi informasi. Pendapat tersebut didasarkan pada kesadaran orang-orang terhadap pemikiran orang lain tentang mereka, sehingga perilaku penggunaan teknologi informasi mereka dipengaruhi oleh perilaku orang-orang atau pengaruh keputusan dalam banyak situasi yang berbeda. Psychological Attachment merupakan perluasan dari social influence.

Dalam penelitian Malhotra dan Galletta (1999) dan Wijayanto (2003) tampak bahwa psychological attachment memiliki pengaruh yang siginifikan terhadap attitude dalam pemanfaatan teknologi informasi.

Berdasarkan penjelasan diatas peneliti akan mengajukan hipotesis pengaruh psychological attachment terhadap attitude dalam pemanfaatanwww.pajak.go.id.

H4: Terdapat pengaruh yang signifikan antara faktor attitude dan behavior intention dalam pemanfaatan www.pajak.go.id. 
Model TAM dari Davis (1989) yang dikutip oleh Kang (1998) menyatakan bahwa penggunaan teknologi ditentukan oleh behavior intention dalam menggunakan teknologi, behaviorintention tersebut dibangun dari attitude. Attitude sendiri dibentuk dari perceived usefulness dan perceived ease of use.

Dalam penelitian Mathieson dan Tod yang dikutip oleh Gardner dan Amoroso (2004) menjelaskan dalam penelitian tersebut diketahui attitude secara statistik adalah valid untuk menjelaskan perhatian untuk menggunakan (intention to use) dengan menggunakan TAM (Technology Acceptance Model). Sedangkan Tod (2004) mengatakan bahwa attitude bukanlah penentu signifikan dari perhatian prilaku (behavior intention) walaupun hubungan antara attitude dan behavior intention adalah lebih signifikan untuk pengalaman pemakai.

Pendapat Davis (1989) yang dikutip oleh Gardner dan Amoroso (2004) menyebutkan bahwa penerimaan teknologi informasi oleh orang-orang yang menggunakan komputer dapat diperkirakan prilakunya (behavior) melalui perhatian prilaku (behavior intention) dalam penggunaan teknologi informasi.

Berdasarkan ilustrasi di atas maka peneliti akan mengajukan hipotesis hubungan antara attitude dan behavior intention dalampemanfaatan www.pajak.go.id.

\section{METODE PENELITIAN}

Kegiatan pengumpulan data dilakukan dengan metoda survei pada masyarakat di wilayah Kalimantan Timur. Provinsi Kalimantan Timur terdiri atas 9 kota/kabupaten. Kota/kabupaten tersebut, yaitu Kota Samarinda, Kota Balikpapan, Kota Bontang, Kab. Kutai Kartanegara, Kab. Kutai Barat, Kab.Kutai Timur, Kab. Berau, Kab. Pasir, dan Kab. Penajam Paser Utara. Waktu penelitian dilaksanakan pada tahun 2013 sampai dengan 2014.

Populasi dalam pengambilan sampel ini adalah masyarakat di wilayah Kalimantan Timur yang berprofesi sebagai akuntan pemerintah yang berada di wilayah Kalimantan Timur. Metode pengambilan sampel adalah secara non probabilitas atau pemilihan non random berupa purposive sampling. Metode pengambilan sampel dengan purposive sampling berdasarkan suatu kriteria tertentu yaitu akuntan yang memanfaatkan website Direktorat Jenderal Perpajakan yaitu www.pajak.go.id.

Model analisis jalur (path analysis) semua variabel laten dalam PLS terdiri dari tiga set hubungan:

a. Inner model yang menggambarkan hubungan antara variabel laten berdasarkan substantive theory (structural model).

b. Outer model mendefinisikan bagaimana setiap blok indikator berhubungan dengan variabel latennya.

c. Weight relation digunakan untuk menciptakan komponen skor variabel laten yang didapat berdasarkan bagaimana inner model dan outer model dispesifikasi. 


\section{HASIL DAN PEMBAHASAN}

Dari 525 eksemplar kuesioner yang disebar, yang diterima kembali sebanyak 316 eksemplar kuesioner dengan tingkat respon sebesar 60\%. Kuesioner yang diterima sebanyak 315 eksemplar telah diisi dengan lengkap oleh responden sehingga dapat diolah dan dianalisis.

Outer model sering juga disebut outer relation atau measurement model yang menspesifikasikan hubungan antara variabel laten dengan indikator atau variabel manifestnya. Model pengukuran atau outer model terdiri atas convergent validity, discriminant validity dan reliabilitas.

Pada tabel 1. tampak hasil pengolahan data dengan menggunakan PLS yang menghasilkan outer loading untuk setiap indikator (variabel manifest) dari variabel laten perceived usefulness (PU), perceived ease of use (PEOU), psychological attachment (PA), attitude dan behavior intention (BI). Dari outer loading tampak nilai loading dari indikator pada kolom original sample estimate. Dari nilai loading tersebut tampak bahwa terdapat nilai loading dibawah 0,50, yaitu X13 dengan 0.487. Pada kolom T-Statistic tampak nilai t hitung indikator X13 dengan 1,287 tidak signifikan pada 0,05 yaitu kurang dari 1,960. Sehingga X13 harus dikeluarkan dari model.

Tabel 1. Hasil Dari Outer Loading

\begin{tabular}{ccccc}
\hline & $\begin{array}{c}\text { Original } \\
\text { Sample } \\
\text { Estimate }\end{array}$ & $\begin{array}{c}\text { Mean of Sub } \\
\text { sample }\end{array}$ & $\begin{array}{c}\text { Standard } \\
\text { Deviation }\end{array}$ & T-Statistic \\
\hline Perceived & & & & \\
Usefulness & & & & \\
X1 & 0,907 & 0,906 & 0,029 & 31,723 \\
X2 & 0,909 & 0,898 & 0,061 & 14,844 \\
X3 & 0,863 & 0,853 & 0,090 & 9,539 \\
X4 & 0,918 & 0,916 & 0,051 & 17,836 \\
X5 & 0,841 & 0,839 & 0,054 & 15,615 \\
X6 & 0,841 & 0,834 & 0,065 & 12,990 \\
& & & & \\
Perceived & & & & 3,537 \\
Ease of Use & 0,659 & 0,625 & 0,186 & 7,225 \\
X7 & 0,733 & 0,720 & 0,101 & 13,872 \\
X8 & 0,818 & 0,818 & 0,059 & 11,486 \\
X9 & 0,840 & 0,843 & 0,073 & 6,909 \\
X10 & 0,698 & 0,700 & 0,088 & \\
X11 & 0,806 & 0,794 & 0,120 & 1,287 \\
X12 & & & & \\
Psychological & & & & \\
Attachment & 0,487 & 0,339 & 0,379 & \\
X13 & & & & \\
X14 & & & & \\
\hline
\end{tabular}




\begin{tabular}{ccccc}
\hline & $\begin{array}{c}\text { Original } \\
\text { Sample } \\
\text { Estimate }\end{array}$ & $\begin{array}{c}\text { Mean of Sub } \\
\text { sample }\end{array}$ & $\begin{array}{c}\text { Standard } \\
\text { Deviation }\end{array}$ & T-Statistic \\
\hline X15 & 0,634 & 0,511 & 0,327 & 1,942 \\
Attitude & 0,973 & 0,840 & 0,361 & 2,700 \\
Y1 & 0,822 & 0,822 & 0,056 & 14,783 \\
Y2 & 0,790 & 0,785 & 0,064 & 12,432 \\
Y3 & 0,807 & 0,805 & 0,074 & 10,935 \\
Y4 & 0,803 & 0,806 & 0,065 & 12,413 \\
Behavior & & & & \\
Intention & & & & \\
Y5 & 0,799 & 0,804 & 0,058 & 13,879 \\
Y6 & 0,823 & 0,818 & 0,070 & 11,759 \\
Y7 & 0,780 & 0,763 & 0,083 & 9,395 \\
Y8 & 0,855 & 0,842 & 0,043 & 19,800 \\
\hline
\end{tabular}

Sumber: Data Diolah Dengan SmartPLS

Setelah dikeluarkannya indikatorX13 maka tampak nilai loading setiap indikator berada diatas 0,50 pada tabel 2 .

Tabel 2. Hasil Dari Outer Loading

\begin{tabular}{ccccc}
\hline & $\begin{array}{c}\text { Original } \\
\text { Sample } \\
\text { Estimate }\end{array}$ & $\begin{array}{c}\text { Mean of Sub } \\
\text { sample }\end{array}$ & $\begin{array}{c}\text { Standard } \\
\text { Deviation }\end{array}$ & T-Statistic \\
\hline Perceived & & & & \\
Usefulness & & & & \\
X1 & 0,907 & 0,906 & 0,029 & 31,723 \\
X2 & 0,909 & 0,898 & 0,061 & 14,844 \\
X3 & 0,863 & 0,853 & 0,090 & 9,539 \\
X4 & 0,918 & 0,916 & 0,051 & 17,836 \\
X5 & 0,841 & 0,839 & 0,054 & 15,615 \\
X6 & 0,841 & 0,834 & 0,065 & 12,990 \\
Perceived Ease & & & & \\
of Use & & & & \\
X7 & 0,659 & 0,625 & 0,186 & 3,537 \\
X8 & 0,733 & 0,720 & 0,101 & 7,225 \\
X9 & 0,818 & 0,818 & 0,059 & 13,872 \\
X10 & 0,840 & 0,843 & 0,073 & 11,486 \\
X11 & 0,698 & 0,700 & 0,088 & 7,909 \\
X12 & 0,806 & 0,794 & 0,120 & 6,731 \\
Psychological & & & & \\
Attachment & & & & 1,699 \\
X14 & 0,586 & 0,520 & 0,345 & 4,950 \\
X15 & 0,992 & 0,928 & 0,200 &
\end{tabular}




\begin{tabular}{ccccc}
\hline & $\begin{array}{c}\text { Original } \\
\text { Sample } \\
\text { Estimate }\end{array}$ & $\begin{array}{c}\text { Mean of Sub } \\
\text { sample }\end{array}$ & $\begin{array}{c}\text { Standard } \\
\text { Deviation }\end{array}$ & T-Statistic \\
\hline Attitude & & & & \\
Y1 & 0,823 & 0,816 & 0,065 & 12,750 \\
Y2 & 0,899 & 0,900 & 0,026 & 10,393 \\
Y3 & 0,910 & 0,905 & 0,029 & 11,676 \\
Y4 & 0,662 & 0,678 & 0,099 & 12,180 \\
Behavior & & & & \\
Intention & & & & \\
Y5 & 0,799 & 0,810 & 0,053 & 14,987 \\
Y6 & 0,823 & 0,801 & 0,111 & 7,400 \\
Y7 & 0,780 & 0,765 & 0,099 & 7,902 \\
Y8 & 0,855 & 0,844 & 0,077 & 11,046 \\
\hline
\end{tabular}

Sumber: Data Diolah Dengan SmartPLS

Mengukur nilai discriminant validity adalah dengan membandingkan nilai akar dari Average Variance Extracted (AVE) setiap konstruk (variabel laten) dengan korelasi antara konstruk lainnya. Jika nilai dari akar AVE lebih besar dari pada korelasi antara konstruk dengan konstruk lainnya berarti setiap konstruk memiliki discriminant validity yang baik.

Dengan membandingkan nilai akar dari AVE setiap konstruk dengan korelasi antara konstruk lainnya seperti yang tampak pada tabel 3. Nilai akar AVE perceived usefulness (dicetak tebal) dengan nilai 0,880 lebih besar dibandingkan korelasi antara konstruk lainnya. Hal tersebut berlaku juga untuk perceived ease of use dengan akar AVE 0,762, psychological attachment dengan akar AVE 0,815, attitude dengan akar AVE 0,806dan behavior intention dengan akar AVE 0,815. Sehingga dapat dikatakan bahwa seluruh variabel laten memiliki discriminant validity yang baik.

Tabel 3. Korelasi Antar Konstruk dan Akar AVE

\begin{tabular}{cccccc}
\hline & $\begin{array}{c}\text { Perceived } \\
\text { Usefulnes }\end{array}$ & $\begin{array}{c}\text { Perceived } \\
\text { Ease of Use }\end{array}$ & $\begin{array}{c}\text { Psychological } \\
\text { Attachment }\end{array}$ & Attitude & $\begin{array}{c}\text { Behavior } \\
\text { Intention }\end{array}$ \\
\hline $\begin{array}{c}\text { Perceived } \\
\text { Usefulness }\end{array}$ & $\mathbf{0 , 8 8 0}$ & & & & \\
$\begin{array}{c}\text { Perceived Ease of } \\
\text { Use }\end{array}$ & 0,701 & $\mathbf{0 , 7 6 2}$ & & & \\
$\begin{array}{c}\text { Psychological } \\
\text { Attachment }\end{array}$ & 0,273 & 0,371 & $\mathbf{0 , 8 1 5}$ & & \\
$\begin{array}{c}\text { Attitude } \\
\text { Behavior Intention }\end{array}$ & 0,533 & 0,598 & 0,414 & $\mathbf{0 , 8 0 6}$ & \\
\hline
\end{tabular}

Sumber: Data Diolah Dengan Smart PLS 
Pada tabel 4, composite reliability tampak bahwa nilai setiap variabel laten berada diatas 0,70 dan nilai AVE setiap varibel laten berada diatas 0,50. Berdasarkan hal tersebut maka seluruh variabel laten memiliki tingkat reliabilitas yang baik.

Inner model disebut juga inner relation, structural model dan substantive theory. Inner model menggambarkan hubungan antar variabel laten berdasarkan pada substantive theory. Menilai inner model adalah melihat hubungan antar konstruk laten dengan memperhatikan hasil estimasi koefisien parameter path dan tingkat siginifikannya. Sehingga pengujian hipotesis dapat dilakukan dengan memperhatikan tingkat signifikan dan parameter path antar varibel laten, seperti tampak pada tabel 5.

Tabel 4. Nilai AVE dan Composite Reliability

\begin{tabular}{ccc}
\hline & $\begin{array}{c}\text { Average Variance } \\
\text { Extracted }(\text { AVE) }\end{array}$ & $\begin{array}{c}\text { Composite } \\
\text { Reliability }\end{array}$ \\
\hline $\begin{array}{c}\text { Perceived } \\
\text { Usefulness } \\
\text { Perceived }\end{array}$ & 0,775 & 0,954 \\
$\begin{array}{c}\text { Ease of Use } \\
\text { Psychological }\end{array}$ & 0,581 & 0,892 \\
Attachment & 0,664 & 0,787 \\
Attitude & 0,649 & 0,881 \\
$\begin{array}{c}\text { Behavior } \\
\text { Intention }\end{array}$ & 0,664 & 0,887 \\
\hline Sumber: Data Diolah Dengan SmartPLS
\end{tabular}

Sumber: Data Diolah Dengan SmartPLS

Dari tabel 5 tampak $\mathrm{T}$ statistik sebesar 1,755 yang lebih kecil dari $\mathrm{T}$ tabel yaitu 1,960 dengan tingkat signifikan 0,05. Hasil uji T tampak bahwa tidak terdapat pengaruh yang signifikan antara perceived usefulness dan attitude dalam pemanfaatan website perpajakan (www.pajak.go.id).

Dari hasil uji $\mathrm{T}$ tampak penerimaan kegunaan (perceived usefulness) dalam pemanfaatan website perpajakan (www.pajak.go.id) oleh responden tidak memiliki pengaruh yang signifikan terhadap sikap (attitude) yang akan mempengaruhi perilaku yang khusus dalam pemanfaatan website perpajakan(www.pajak.go.id). Hasil yang diperoleh berbeda dengan penelitian yang dilakukan oleh beberapa peneliti yang lain seperti Darsono (2005) dan Wijayanto (2003).

Weber (1999) menjelaskan bahwa faktor lain mungkin akan mempengaruhi penerimaan kegunaan (perceived usefulness) dari sistem informasi seperti implementasi suatu sistem menghasilkan pengaruh yang tidak menguntungkan atas kebiasaan bekerja pemakainya walaupun teknologi itu secara potensial dapat meningkatkan kinerjanya. Hal tersebut disebabkan pengaruh sosialisasi dan kebiasaan dalam bekerja serta infrastruktur mempengaruhi pemanfaatan website perpajakan(www.pajak.go.id). 
Tabel 5. Estimasi Koefisien, T Statistik dan R-Square

\begin{tabular}{lcccc}
\hline & $\begin{array}{c}\text { Original } \\
\text { Sample } \\
\text { Estimate }\end{array}$ & $\begin{array}{c}\text { Standard } \\
\text { Deviation }\end{array}$ & $\begin{array}{c}\text { Standard } \\
\text { Deviation }\end{array}$ & T-Statistic \\
\hline PU -> Attitude & 0.218 & 0.124 & 0,124 & 1.755 \\
PEOU -> Attitude & 0.364 & 0.173 & 0,173 & 2.098 \\
PA -> Attitude & 0.220 & 0.125 & 0,125 & 1.755 \\
Attitude -> BI & 0.599 & 0.092 & 0,092 & 6.535 \\
\hline
\end{tabular}

Sumber: Data Primer Diolah Dengan Smart PLS

Kurangnya sosialisasi Direktorat Jenderal Perpajakan terhadap pemanfaatan website perpajakan (www.pajak.go.id) mempengaruhi tingkat penerimaan pemanfaatan website perpajakan. Sehingga ketidaktahuan tersebut menjadi penyebab utama atas kurangnya tingkat penerimaan pemanfaatan website perpajakan.

Faktor lainnya adalah kebiasaan bekerja. Dalam pelaksanaan peranannya, akuntan pemerintah memiliki kewajiban untuk memotong pajak dari anggaran yang digunakan dalam kegiatan di dinas tempatnya bekerja. Dalam pelaksanaan tugas tersebut, mereka kadang menghadapi permasalahan-permasalahan terkait informasi terbaru mengenai ketentuan perpajakan.Para akuntan pemerintah tersebut terbiasa untuk memperoleh jawaban dari permasalahan tersebut dengan melakukan konsultasi langsung kepada Kantor Pelayanan Pajak.

Faktor terakhir adalah faktor kurangnya dukungan infrastruktur.Dalam memanfaatkan website perpajakan, infrastruktur yang terkait dengan pengadaan jaringan internet di bagian keuangan sangat dibutuhkan.Dengan tidak tersedianya jaringan internet pada bagian bendahara keuangan menyebabkan kurangnya pemanfaatan website perpajakan.

Dari tabel 5 tampak $\mathrm{T}$ statistik sebesar 2,098 yang lebih besar dari $\mathrm{T}$ tabel yaitu 1,960 dengan tingkat signifikan 0,05 . Hasil uji $\mathrm{T}$ tampak bahwa terdapat pengaruh yang signifikan antara perceived ease of use dan attitude dalam pemanfaatan website perpajakan(www.pajak.go.id).

Heslin (1996) menyatakan bahwa orang-orang yang berbeda menunjukkan persepsi yang berbeda-beda terhadap kemudahan dalam menggunakan teknologi informasi terhadap sistem yang sama. Hal tersebut menunjukkan bahwa perbedaan pekerjaan akan mempengaruhi penerimaan terhadap kemudahan dalam menggunakan teknologi informasi dengan sistem yang sama karena setiap orang memiliki pengalaman dan kemampuan yang berbeda dalam menggunakan teknologi informasi.

Dari hasil uji T tampak penerimaan kemudahan menggunakan (perceivedease of use) dalam pemanfaatan website perpajakan (www.pajak.go.id) memiliki pengaruh yang signifikan terhadap sikap (attitude) yang akan mempengaruhi perilaku yang khusus dalam pemanfaatan website perpajakan (www.pajak.go.id). Penelitian dengan menggunakan hipotesis pengaruh perceived ease of use terhadap attitude juga dilakukan Hubona dan Geitz (1997), Malhotra dan Galletta (1999) dan Wijayanto (2003) dan memberikan hasil yang sama dengan penelitian ini. 
Dari tabel 5 tampak T statistik sebesar 1,755 yang lebih kecil dari $\mathrm{T}$ tabel yaitu 1,960 dengan tingkat signifikan 0,05. Hasil uji T tampak bahwa tidak terdapat pengaruh yang signifikan antara psychological attachment dan attitude dalam pemanfaatan website perpajakan(www.pajak.go.id).

Dari hasil uji T tampak pengaruh psikologis (psychological attachment) tidak memiliki pengaruh yang signifikan terhadap sikap (attitude) yang akan mempengaruhi perilaku yang khusus dalam pemanfaatan website perpajakan. Hal tersebut berbeda dengan penelitian yang dilakukan oleh Malhotra dan Galletta (1999) tampak bahwa psychological attachment memiliki pengaruh yang siginifikan terhadap attitude dalam penerimaan teknologi informasi.

Dari tabel 5 tampak T statistik sebesar 6,535 yang lebih besar dari $\mathrm{T}$ tabel yaitu 1,960 dengan tingkat signifikan 0,05. Hasil uji $\mathrm{T}$ tampak bahwa terdapat pengaruh yang signifikan antara attitude dan behavior intention dalam pemanfaatan website perpajakan(www.pajak.go.id).

Dari hasil uji $\mathrm{T}$ tampak sikap (attitude) dalam pemanfaatan website perpajakan (www.pajak.go.id) oleh responden mempengaruhi perilaku yang khusus secara signifikan melalui perhatian perilaku (behavior intention). Hal yang sama juga terlihat pada penelitian yang dilakukan Xu dan Yu (2004) dan Sun dan Zhang (2006).

\section{SIMPULAN DAN SARAN}

Setelah melakukan analisa atas variabel penerimaan kegunaan (perceived usefulness), variabel penerimaan kemudahan menggunakan (perceived ease of use)dan variabel pengaruh psikologis (psychological attachment) yang berpengaruh terhadap variabel intervening sikap (attitude) yang mempengaruhi perilaku yang khusus dalam penerimaan teknologi informasi melalui variabel perhatian perilaku (behavior intention), maka dapat disimpulkan:

a. Tidak terdapat pengaruh yang signifikan antara variabel perceived usefulness dan attitude dalam pemanfaatan website perpajakan (www.pajak.go.id).

b. Terdapat pengaruh yang signifikan antara variabel perceived ease of use dan attitude dalam pemanfaatan website perpajakan (www.pajak.go.id).

c. Tidak terdapat pengaruh yang signifikan antara variabel psychological attachment dan attitude dalam pemanfaatan website perpajakan (www.pajak.go.id).

d. Terdapat pengaruh yang signifikan antara variabel attitude dan behavior intention dalam pemanfaatan website perpajakan (www.pajak.go.id).

Variabel perceived usefulnessdan psychological attachment tidak memiliki pengaruh yang signifikan terhadap attitude dalam pemanfaatan website perpajakan (www.pajak.go.id). Hal tersebut dikarenakan faktor kurangnya sosialisasi, infrastruktur, dan kebiasaan bekerja dalam proses implementasi teknologi informasi akan menghasilkan pengaruh yang tidak menguntungkan walaupun teknologi itu secara potensial dapat meningkatkan kinerja. Oleh karena itu, kami memberikan saran-saran sebagai berikut: 
a. Perlunya sosialisasi Direktorat Jenderal Perpajakan terhadap pemanfaatan website perpajakan (www.pajak.go.id) kepada para akuntan terutama akuntan pemerintah. Hal ini karena kurangnya sosialisasi mempengaruhi tingkat penerimaan pemanfaatan website perpajakan. Ketidaktahuan tersebut menjadi penyebab utama atas kurangnya tingkat penerimaan pemanfaatan website perpajakan.

b. Pimpinan instansi tempat akuntan bekerja terutama instansi pemerintah daerah, perlu mengintensifkan akuntannya dalam pelatihan/diklat dalam rangka mengoptimalkan pemanfaatam website pajak tersebut, sehingga akan meningkatkan efektifitas dan efisiensi penatalaksanaan perpajakan di instansi masing-masing. Hal ini karena akuntan pemerintah memiliki kewajiban untuk memotong pajak dari anggaran yang digunakan dalam kegiatan di dinas tempatnya bekerja. Dalam pelaksanaan tugas tersebut, mereka kadang menghadapi permasalahan-permasalahan terkait informasi terbaru mengenai ketentuan perpajakan. Para akuntan pemerintah tersebut terbiasa untuk memperoleh jawaban dari permasalahan tersebut dengan melakukan konsultasi langsung kepada Kantor Pelayanan Pajak tanpa memanfaatkan terlebih dahulu fasilitas teknologi informasi dan komunikasi berupa website perpajakan (www.pajak.go.id).

c. Pimpinan instansi pemerintah perlu menyediakan insfrastruktur teknologi informasi dan komunikasi khususnya jaringan instalasi internet, terutama pada bagian yang mengurusi masalah keuangan dan perpajakan. Dalam memanfaatkan website perpajakan, infrastruktur yang terkait dengan pengadaan jaringan internet di bagian keuangan sangat dibutuhkan. Dengan tidak tersedianya jaringan internet pada bagian bendahara keuangan menyebabkan kurangnya pemanfaatan website perpajakan. 


\section{DAFTAR PUSTAKA}

Darsono, Licen Indahwati. (2005). Examining Information Technology Acceptance By Individual Professionals. Gadjah Mada International Journal of Business, Vol. 7, No. 2, pp. 155-178.

Gardner, Christina; Amoroso, Donald L. (2004). Development of an Instrument to Measure the Acceptance of Internet Technology by Consumers. Proceedings of the 37th Hawaii International Conference on System Sciences.

Hartono, Jogiyanto. (2005). Sistem Teknologi Informasi. Andi Offset, Yogyakarta.

Heslin, J. Alexander. (1996). How Critical is Ease of Use in Adopting an Information Technology. An Empirical Study, Proceedings of the 3rd Symposium on Human Interaction with Complex Systems (HICS '96) (C) IEEE.

Hubona, Geoffrey S.; Geitz, Sarah. (1997). External Variables, Beliefs, Attitudes And Information Technology Usage Behavior. Proceedings of The Thirtieth Annual Hawwaii International Conference on System Sciences ISBN 0-8186-7862-3/97 IEEE.

Kang, Sungmin. (1998). Information Technology Acceptance: Evolving with the Changes in the Network Environment. Center for Information Systems Management, Department of Management Science and Information Systems, 1060-3425/98, IEEE.

Malhotra, Yogesh; Galletta, Dennis F. (1999). Extending the Technology Acceptance Model to Account for Social Influence: Theoretical Bases and Empirical Validation. Proceedings of the 32nd Hawaii International Conference on System Sciences.

Senn, James A. (1998). Information Technology In Business: Priciples, Practices and Opportunities. New Jersey: Prentice-Hall, Second Edition.

Succi, Melissa J.; Walter, Zhiping D. (1999). Theory of User Acceptance of Information Technologies: An Examination of Health Care Professionals. Proceedings of the 32nd Hawaii International Conference on System Sciences.

Sun, Heshan; Zhang ,Ping. (2006). The Role of Moderating Factors in Usert Technology Acceptance. School of Information Studies, Syracuse University, USA.

Turban, Efraim; Mclean E.; Wetherbe J. (1999). Information Technology for Management:Making Connections for Strategic Advantage. New York: John Wiley dan Sons, Second Edition.

Umarji, Medha; Emurian, Henry. (2005). Acceptance Issues in Metrics Program Implementation. 11th IEEE International Software Metrics Symposium (METRICS 2005) 1530-1435/ IEEE (C).

Weber, Ron. (1999). Information System Control And Audit. Prentice Hall.

Wijayanto, Arif. (2003). Faktor-Faktor Yang Mempengaruhi Akuntan Publik Dalam Menerima Teknologi Informasi Dalam Proses Audit. Skripsi S1, Fakultas Ekonomi, Universitas Gadjah Mada, Yogyakarta. 